\title{
Effects of Using Technological Innovations on Developing Tourism Education and Learning Methods: Paradigm Shift from Learning Outcomes Perspective Yasser Moustafa Moustafa Shehawy \\ Faculty of Tourism and Hotels, University of Sadat City, Egypt Faculty of Arts and Humanities, Jazan University, KSA
}

\begin{abstract}
Fostering e-learning information and communication technologies (ICTs) in tourism are used to explain how technological innovations improving the tourism learning outcomes. Technological innovations can be used in enhancing tourism knowledge, experiences and employment skills provision, and adapting work-experienced maximization methods. The aims of the study are: putting substantial improvements guidelines in quality of tourism educational process, measuring effects of using technological tools and possibilities on developing tourism education and learning methods, explaining how learning outcomes interrelated with tourism employability and job competitiveness, and putting paradigm shift from learning outcomes perspective. Wide random sample approach used to maximize accuracy and realistic primary data collection process, 540 valid respondents were collected from tourism education academic staff and employees. The structure model analysis depends on using SPSS V.21, and Smart Partial Least Squares and Structural Equation Modeling (SmartPLS-SEM 3.0) programs. They were applied to conduct descriptive analysis, relationship intermediates, factor loadings and reliability, cross loadings, discriminant validity and convergent validity of study model.

The analysis of the discussed variables in the current study comprises; technological innovation tools, characteristics, reasons and justifications, tourism curriculum mapping design measurements, Kolb's learning styles modes, Bloom's digital taxonomy and Web2.0 social media, employability competitiveness, learning outcomes, future of innovative technology tools, and future of traditional classroom tools. The major findings from the study model supported and confirmed significant relationships between tourism learning outcomes and the following five main variables: tourism curriculum mapping design measurements, Kolb's learning styles modes, Bloom's digital taxonomy and Web2.0 social media, and employability competitiveness as reflective and formative indicators. Moreover, obtained findings recognized effects and supported positive relationships between using technological innovations on tourism learning outcomes in the future, and employability and job competitiveness. In contrast, findings supported negative relationships between using traditional classrooms systems on tourism learning outcomes in the future, and on employability and job competitiveness. The study ended with integrated complex paradigm shift in tourism e-learning links.

Keywords: Technological Innovations, Tourism Learning Outcomes, e-Learning, Tourism Employability, SmartPLS-SEM, Kolb, Bloom, Web2.0 Social Media

\section{Introduction}

Today, there is tremendous variety of complex education methods based technological systems, which globally spread drastically in Higher Education (HE) along with internet and ICTs spreading (Abbas et al. 2016). Romiszowski (2004); Conrad (2006); and Sigala (2012) explained that with the apparent of new technologies. The e-learning term is widely used to describe; online learning, web-based training, technology based training, mediated learning, online collaborative learning (OCL), virtual learning, and web-based learning, etc.. This term can be described as access to more attractive learning experiences via the use of some innovative
\end{abstract}


technologies (Garrison, and Kanuka, 2004; Conrad, 2006; Halawi et al. 2009; Moore et al. 2011). Such technologies provide connectivity, flexibility and ability to promote varied learning interactions (Ally, 2004; Hiltz and Turoff, 2005; Oblinger and Oblinger, 2005; Halawi et al. 2009), and enhance cognitive skills (Songkram et al. 2015) without conflict with family or work (Hošková-Mayerová and Rosická 2015) with easing off classes overloaded (Afifi, 2011). Eleaning can enhances the quality of education over innovative methods by incentivizing students' motivations, interests and engagements, enabling attainment of skills, and improve communication and exchange of information (Pavel et al. 2015). Eftimie (2013) introduced that updating use of innovations in teaching techniques benefited in linking education environment with labor market requests. Generally, technological innovations investigated in this study regarding tourism e-learning methods improve the students' learning experience and performance. They are derived from internet based tools that provide interactivity, connectivity and convergence such as programmed learning, interactive videos and video conferencing (Cobanoglu and Berezina, 2011; Eftimie, 2013; Tarhini et al. 2013; Pavel et al. 2015). Education integration (Co-Operation) and automated coded Computer Assisted Instructional Package (CAIP) programs facilitate evaluations, assessments, and feedback mechanism in accessibility, simply and desired format. CAIP makes learning exciting, interesting and challenging. It enables monitoring learner strength and deficit, makes self-learning flexible, and students can work anywhere by computer with or without internet connection (Fakomogbon et al. 2014). In this concern, distance learning provide distributed technological education accessibility process opportunities in geographically distant and time removal (King et al. 2001; UNESCO, 2002; Halawi et al. 2009; Moore et al. 2011).

A recent free e-learning education innovation "Massive Open Online Courses MOOCs" help addresses tourism industry, academic education, and training issues (Murphy et al., 2014; Murphy et al. 2015). Also, mobile subset considered recent blended learning method which allows obtaining learning materials anytime anywhere by using mobile devices (Al-Hunaiyyan $e t$ al., 2016). It provides collaborating Meta data (Semantic Web) (Kontopoulos et al., 2008) enriching linked open data (LOD) availability, convenient, permitted data reuse and redistribution (Fermoso et al. 2015). In this context, Moore et al. (2011); McGee and Reis, (2012) conclude that Online Learning Environment (OLE) tools comprehensively describe; Learning Management System (LMS) for online courses, Course Management System (CMS) used to describe tools of internet based courses, Virtual Learning Environment (VLE), Blended Learning Environment (BLE) (Songkram et al. 2015), and even a Knowledge Management System (KMS). 3D virtual learning of second life tools used for tourism educations. It provides students with real-world simulations, social interactions, engagement, and collaborative spaces (Huang et al., 2013). Romiszowski (2004) stated that successful e-learning environment has three key elements: prescriptive assessment (personalized plans), live labs (provide students performance-based learning experience), and Multi-sensory learning tools (students engaged and improve retention), the design depends on objective, target audience, access, and type of content (Moore et al. 2011). It consists of four core elements: input, process, output, and feedback (Songkram et al. 2015). In Egypt, e-learning has been adapted as a teaching strategy to overcome challenges of traditional learning style; over-crowded classrooms, low financing of education, governance and management of the education system, and quality assurance (El-Khouly, 2010). 


\section{Literature Review}

\section{Tools and Characteristics of e-learning environment}

Today, one of the most important themes in enhancing successful tourism education is ensuring that tourism education and training keep up with new technological developments. Technology integration, constructivism, and learning style theory influenced the progress in tourism education environment (Solvie and Kloek, 2007; Sigala, 2012). ICTs tools aligned to learning styles have been used to engage students, support learning, content delivery, and enriching interactive learning by doing and seeing experiences (Pittman et al., 2006; Solvie and Kloek 2007). Technology tools used during and outside classroom presentations to communicate and clarify courses concept and content while engaging with information and feedback (Solvie and Kloek 2007; Eftimie, 2013). Murphy et al., (2015) concluded four online learning categories; resources, tutorials, Online courses (OCs) similar a traditional Face to Face (f2f) class with online e-courses assessment with official successful completion certification, and MOOCs free of charge open OCs. There are four main steps to build a successful e-learning system environment (Romiszowski, 2004; Halawi et al., 2009; Eftimie, 2013; Songkram et al., 2015; Pavel et al., 2015): Step 1: Input or e-learning multimedia content designed with suitable log on system. Elements of input analyzed learner's role, instructor's role, environment, reinforcement, and motivation. Step 2: Process or build content and delivery infrastructure and perform constrictions. It includes activities, creative and systematic thinking processes in tourism. Step 3: Output or create comprehensive support services allowing interactivity, tools as e-mail, and 24 $\mathrm{x} 7$ chat, and gaining cognitive skills as tourism creative, analytical thinking. Step 4: Feedback process includes assessment formative and summative evaluations, handed out assignments gradually, and improving teaching plan and activities.

The reasons of e-learning use controversy, challenges, and mistakes or failure levels are in the following three levels (Romiszowski, 2004; Kluge and Riley, 2008; Halawi et al., 2009; ElKhouly, 2010; Afifi, 2011; Huang et al., 2013; Pavel et al., 2015; Adukaitea et al., 2016): The course levels: require advanced resources, poor quality of course flexibility, poor e-classroom design, ill-performing technology, limited social interaction, slow instructor/mentor response times, encountering disruptive players, virtual violence, assault, and harassment in VLE. The teacher levels: adequate time for e-environment familiarity, learner attitude anxiety elimination, low interest and motivation, poor internet self-efficacy skills, and poor time management skills. Also, disrupting life interruptions, lack of necessary interactions e-skills, psychological students resistance or prefer regular classroom setting f2f communication. The organizational level: poor internal marketing of courses, lack of clear reward structure, technology problems, lack of remuneration fund, failure to provide managerial support or training time, corporate-wide lack of dedication to a learning culture, blanket mandate of e-learning; removal of all other methods, and failure to match internet training to its most purposes. Finally, OECD (2016) pointed out that to ensure best use of technological innovations practices in tourism educations; a series of discussions should gradually implemented between tourism governmental, educational institutes, and industry associations to review tourism vocational training and education system in the light of new tourism labor market trends and needed learning outcomes and skills. Accordingly, it is possible to propose the following hypotheses (Fig.1):

Hypothesis One (H1): Using various technological innovation tools in tourism learning will positively affect the tourism learning outcomes

Hypothesis Two (H2): Applying technological innovation characteristics in tourism learning will positively enhance the tourism learning outcomes 
Hypothesis Three (H3): Reasons or justifications of using technological innovation tools in tourism education methods have a significant impact on tourism learning outcomes

\section{Tourism Curriculum Mapping Courses Design}

During the recent years, e-learning curricula have been in the interest for impacted software based education area (Kontopoulos et al., 2008; Lwoga, 2012). Studies found improved workplace of students when integrated work based practices into the university curriculum design (Baker et al., 2011; Eftimie, 2013). Curriculum should remark objectives concerning behavior, information, and evaluate students' performance (Halawi et al., 2009). Twining (2009) discussed that virtual environment enable infusing playfulness into course design (Liburd and Hjalager, 2010). Murphy et al., (2015) stated that ICTs are powerfully global educational platform regarding their characteristics that impact learning instructional design and curricula. Buhalis and Law (2008) claimed that VLE facilitate course organization, activities, and learning discussion. Tourism curriculum design approaches varied because of its inter-disciplinary nature, multiplicity of stakeholders, and highly tourism industry complex features (Zagonari, 2009). According to Wan et al., (2013), internship into curriculum had a positive impact on a student's personal growth. Scarce studies examined relationship effects of using technological innovation on tourism curriculum mapping and design. Murphy et al., (2015) emphasized that with internet access free MOOC, receiving feedback, grades and certification are available for all. The so called co-operative education improves students' grade average and in turn had a significant effect on the learning outcomes (Blair and Mille, 2004).

According to Liburd and Christensen (2013) continuous curricula adaptation is highly significant in setting objectives for integration of web 2.0 learning activities in tourism. Educational institutions should lead tourism private sector to offer clear links between curricula and career paths in tourism curriculum design. Accordingly, merging tourism learning theoretical knowledge with practical, internship, and social experiences positively impact tourism learning outcomes (Zagonari, 2009; Knowles et al., 2003; Pavel et al., 2015). Murphy et al., (2015) conceptualize improving tourism learning by three main online assessment; students/ learner to content (S2C), student/ learner to student/ learner (S2S), and student/ learner to teacher/trainer/tutor (S2T) that actually applied in some universities around the world. The assessment criteria concerning e-curriculum mapping design should correctly inform students where they went wrong and why, with corrective advice on areas for improvement (Nicol and Macfarlane-Dick, 2006). The feedback process improves student performance on future assessments, it increases positive perceptions of e-learning, such as WebCT program that used for tourism learning assignments, discussions, course material, e-mails, exams, and tests (Halawi et al., 2009). Furthermore in e-learning, recognition is a key variable concerning online participation certification success. It relates positively to budgetary charge and granting providers; formal tourism recognition may charge the MOOCs (Murphy et al., 2015). Moreover, blended course design (BCD) is deeming to be the most suitable shape for tourism related to learning outcomes. The categorization of $\mathrm{BCD}$ combines elements of $\mathrm{f} 2 \mathrm{f}$ classroom learning experience and online courses effectively. Furthermore, BCD provides a considerable portion of learning content online, and relying on discussions within a planned and educationally driven structure (Garrison, and Kanuka, 2004; McGee and Reis, 2012; Songkram et al., 2015). Songkram et al., (2015) estimated seven main core elements of e-learning design methods; econtents, learning management system, communication and evaluation, teacher's role, student's role, provider's role, and teaching method. There are eight listed key dimensions threats when 
putting e-learning curriculum mapping design; educational, institutional, technological, interface design, evaluation, management, resource support, and ethical considerations (Romiszowski, 2004). This study proposed providing tourism courses in Jet Audio, sound record, screen cast programs (recode Multimedia format) then providing it in https://support.google.com/youtube. Also, providing tourism courses contents by using info-graph design program (http://www.easel.ly) or by scanning the identified code by mobile devices. In addition, using Google Drive in designing assessments, training courses, exams, recording or monitoring learning progress, mark achievements and gained experienced, and building personal interactive links for grading systems between institution, teacher and learner. Accordingly, it is possible to propose the following hypothesis (Fig.1):

Hypothesis Four (H4): Using TI tools in curriculum mapping design measurements in tourism education methods have a significant impact on tourism learning outcomes

Figure 1: The study model constructs framework and hypotheses

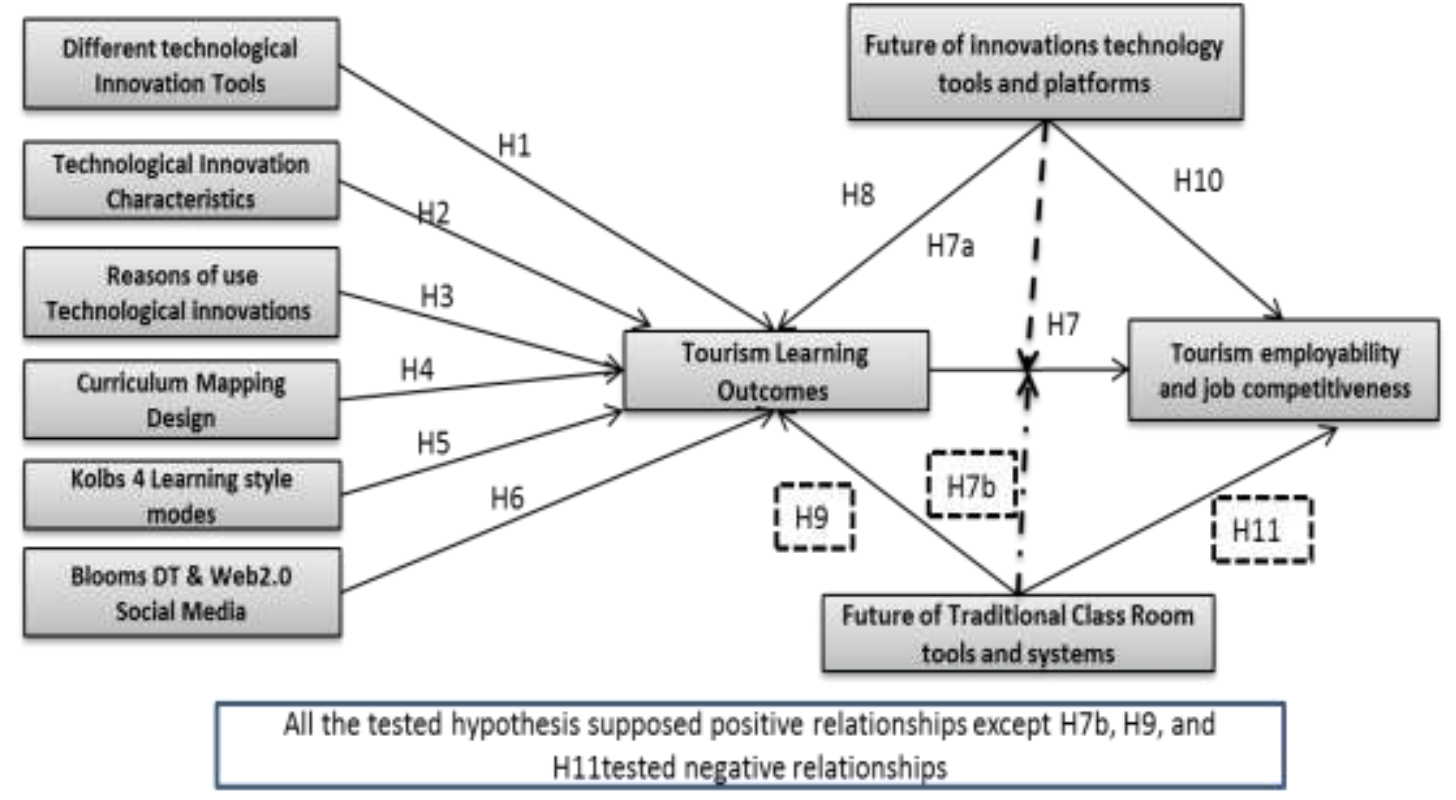

\section{Modification of Kolb's Experiential Learning Styles}

Experiential learning (EL) defined as learning from experience. It is evident that student gained practical experiences. It provides a significant academic link with industry (Yang and Cheung, 2014) and bridging the divide between academic knowledge and practical skills (Ruhanen, 2005). Accordingly, guarantee that tourism learning outcomes regarding employability skills can meet industry requirements. EL style is positively influenced by specific environmental demands of specialization, career, job, and tasks skills (Kolb and Kolb, 2005). David A. Kolb's learning style model and construction (Kolb, 1984; Kolb and Kolb, 2005) basically used and developed in this research regarding tourism learning methods by innovation technology. According to David A. Kolb's, EL makes students more motivated to learn where they can see and understand relevance in a real world setting and often occurs by interactions outside classroom (Stansbie $e t$ al., 2016). The Kolb's EL modes include progress of learning creative and critical thinking skills, practical experience for employability improvement, combination of various coursework components, and enhances learning satisfactions and self-confidence (Papamarcos, 2002; Kolb and Kolb, 2006).The four coordinate's tools of EL cycle according to Kolb's learning style 
model are shown in Figure (2) (Kolb, 1984; Kolb and Kolb, 2006; Solvie and Kloek, 2007): Feelings or concrete experience in north axis. It explains ability to perceive and deals with information and its interactions. In this stage, students' engage in experiences related to different literacy outside the classroom and apply skills to real life problems. Sharing knowledge socially within groups has been involved. Watching or reflective observation in east side explains how learners process and transform information. It reflects or reacts to experiences, use expert interpretation and guidance. Thinking or abstract conceptualization (analysis) and generalization (conclusions) was in south axis. It explains ability to perceive and deal with information structure and function. It includes getting information from authoritative sources, using research and methods, and engaging in theory reading. Doing or active experimentation (actively test the hypothesis) was in west side resulting in new experience. It explains how learners process and transform information from all styles; it is used in assessing students' knowledge and skills, using redesigning information and applied it in problem solving, assignments or field experiences, and discussing the work. Move maker or clips tools are considered significant types to discuss and interact between parties.

Accordingly, Ghanekar, (2011); Hsu and Wu, (2014) modified the Kolb's four main tools; To assist student's concrete experience an electronic smart whiteboard, use of audio clips on a course Web page, and video clips viewed in class, and posted for review on the course Web page were incorporated.To assist student's watching or reflective observation within collaborative groups and enhance metacognitive skills to literacy using inspiration software to provide broad overviews of courses topics and concepts. Assist student's thinking or abstract conceptualization by using power point presentation software or via hyperlinks in course web page to provide review of literacy topics discussed in class. It allows sharing social construction of knowledge and experiences. Assist student's doing or active experimentation by IT tools such as smart board, smart notebook software. It allows discussion, problem-solving assignments and feedback. According to Coffield et al., (2004) and Hsu and Wu (2014) Kolb four types of learning styles can be continuously linked in four main relations:

- The diverging style (concrete, reflective). It is an observation feeling-oriented and aware of meanings and values; (from having to reviewing an experiencing)

- The assimilating style (abstract, reflective). It includes creating theoretical models, ideas and abstract concepts; (from reviewing to concluding an experiencing).

- The converging style (abstract, active). It is preferable in technical problem-solving, decision-making, and practical application; (from concluding to planning next step).

- The accommodating style (concrete, active). It carries out plans and gets involved in new experiences (from planning the next step to having a new experiencing). 
Figure 2: Tourism Kolb's four learning styles modes using technological innovations

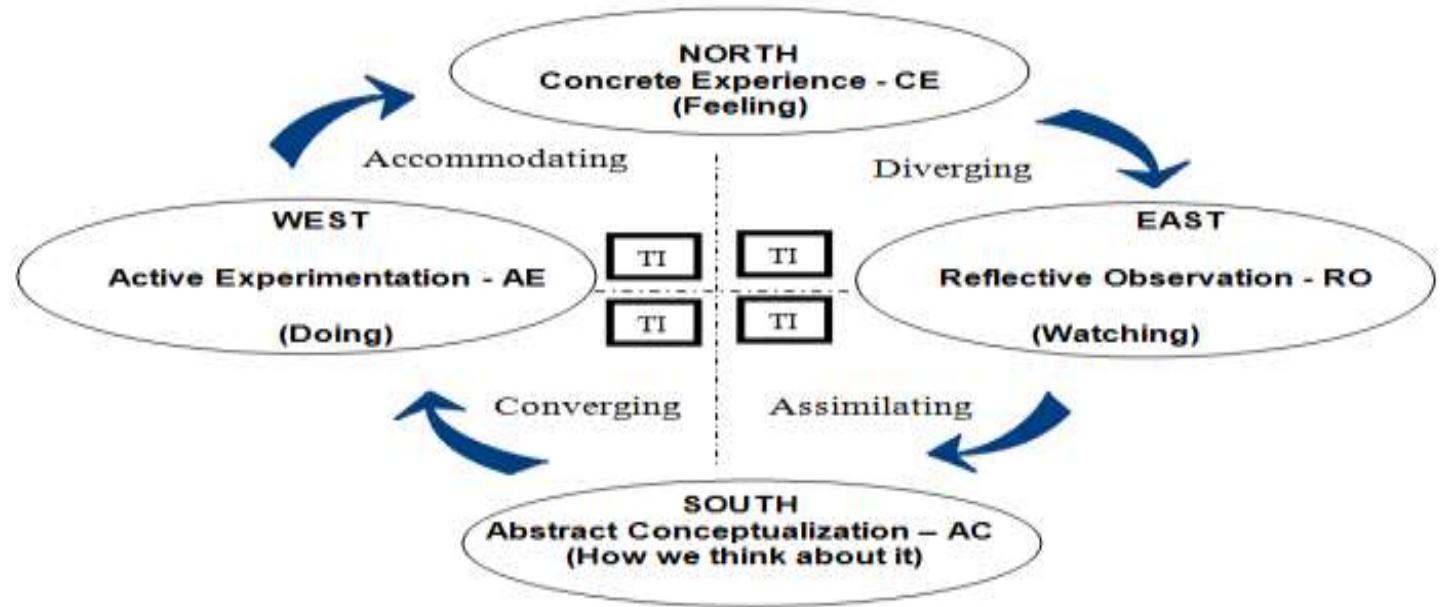

TI: Technological Innovations

Modified by author from: Coffield et al., (2004); Hsu and Wu, (2014); Kolb, (1984); Zull (2002); Kolb and Kolb, (2005-2006); Ruhanen, (2005).

Solvie and Kloek (2007) concluded that knowledge construction can be generated when using Kolb's four modes by technology tools. Accordingly, using EL approaches in tourism education enhances students' interest, motivation, participation, knowledge, and skills development (Ruhanen, 2005). However, it is widely noted that Kolb's learning style model did not measure influenced role played by ICTs innovations and environments (positive, negative, no influence). The current study investigates modified Kolb's experiential learning styles (figure 2) to be applied in tourism with new modes and constructivism triggering by innovation technology. Accordingly, the present study suggests the following main related Kolb's learning style hypothesis (Fig.1):

Hypothesis Five (H5): Using modified Kolb's learning styles modes in tourism education will positively enhance tourism learning outcomes

\section{Using Bloom's digital taxonomy and Web2.0 Social Media}

The so called Bloom's taxonomy- higher forms of thinking in education is a merging theory and practice in classifying significant and evaluating educational objectives (Bloom, 1956). Although it widely used in assessing students' course performance in traditional classroom environment, it rarely used to evaluate e-learning setting (Halawi et al., 2009) in tourism. The taxonomy composes of six hierarchically prepared groups of objectives by motivating cognitive, affective and psychomotor concentrations through creating more comparative forms of education (Karaskova 2014; Halawi et al., 2009). Bloom's cognitive objectives, methods and tools applications are integrated with Web2.0 social media. It can be suitability applied in tourism education through the following dimensions from low to high complexity levels (Anderson and Krathworthl, 2001; Betts, 2008; Halawi et al., 2009; Karaskova, 2014):

1. Remembering: memorizing and recollecting knowledge (tourism facts or important events).

2. Understanding: constructing on base of acquired statements. It includes oral, written, and graphic expressing as describing of terrorism effects in tourism and detailed relationships.

3. Applying: using structure in various situations (e-marketing in crisis problem solving).

4. Analyzing: dividing issue into parts and relations to the total structure as how would insert innovation of the strategy of the enterprise of tourism? 
5. Assessing: given criteria and standards as analyzing alternatives to judge which method is better for solving the given tourism problem.

6. Creating: creating new inner compound complexes and reorganizing elements into new structure as making tourism issues judgments and resolving differences.

Halawi et al., (2009) reviewed that Bloom's taxonomy used in course development, provides outcomes, realizes activities, and assessments of objectives achievement. Accordingly, utilizing Bloom's taxonomy should be reflected in tourism educational objectives, knowledge, developments and practical innovative needs, and matching graduating competencies with future tourism labor market requirements (Karaskova, 2014). Betts (2008) confirmed that Bloom's typology is significantly used in course or curriculum development and design regarding knowledge skills. Also, discussion board, quizzes, and portfolio scored high regarding application and analysis. In addition, project and portfolio scored high regarding evaluations. Web 2.0 termed pedagogy 2.0 social media emerging not only as learning tools but also in evaluation and assessment. It provides a learning joint platform and mimicking for tourism students, teachers, businesses and researchers (Liburd and Hjalager, 2010). It provides flexible ways to communicate, present content, create, editing, sharing, and collaborate active user generating content (UGC) (Lwoga, 2012). Web2.0 tools are easy free to learn, use and implement. Accordingly, web 2.0 educational design provides interaction, joint creation of content, critical thinking and collaboration between students and teachers both $\mathrm{f} 2 \mathrm{f}$ and online via social media such as discussion forums, blogs and wikis, social networking sites (SNS) as Facebook, video blogs, YouTube, slide share, Flickr and RSS feeds (Postigo, 2011; Lwoga, 2012; Liburd and Christensen, 2013; Lin et al., 2013; Pavel et al., 2015). The process of providing grading and assessments feedback are believed as being 'bread and butter to teaching and learning' (Boud, 2000:155; Semley et al., 2016) and lifeblood of tourism communicate elearning tools. Overall, web 2.0 enables forms of collaboration and participation in knowledge construction online (Liburd and Hjalager, 2010; Sigala, 2012; Lwoga, 2012). Student's five stages of VLE tools in Web2.0 social media are (Lwoga, 2012; Liburd and Christensen, 2013); creating a VLE to log onto platform to mark presence and e-moderator welcomes students and ensure providing support tools and help gateway, processing students' online socialization and start browsing online activities, involves academic activities and professionally discussion information, analysis, students build knowledge together and interpretations in a collaborative manner, and students familiars with online environment and globally expand their virtual horizons. Accordingly, the study modified Kolb's learning styles modes by the following hypothesis (Fig.1):

Hypothesis six (H6): Using Bloom's Digital Taxonomy and Web2.0 or social media in tourism education will positively enhance tourism learning outcomes

\section{Learning Outcomes and Employability in tourism}

Learning outcomes are enhanced by educational process as a benchmark for assuring quality and efficiency. It enables universities to describe program and course design in an explicit way (Maher, 2004; Betts, 2008). Hošková-Mayerová and Rosická (2015) and Pavel et al., (2015) introduced that e-learning process enriches suitable teaching courses, training programs and teaching methods related to learning outcomes. Sigala (2012) stated that fostering desired elearning outcomes are completed only when e-learning activities aligned with suitable eassessment methods and strategies. In addition, blended learning approaches respect learning outcomes when exchange ideas in classroom and learning social media, therefore students gained 
desired satisfaction, retention and achievement (Garrison, and Kanuka 2004; Afifi, 2011; McGee and Reis, 2012). Accordingly, all tourism education institutions should commit using TI tools and applications for ensuring special tourism students' competitive outcomes in the future (Singh and Lee 2008). Many e-learning studies focused largely on staff experience where little attention paid to student's perceptions, attitude and engagement in tourism field (Cantoni et al., 2009; Eraqi et al., 2011; King and So, 2014). However, there are little previous studies focus on measuring the effects of e-learning on tourism learning outcomes and employability (Abbas et al., 2016). Songkram et al., (2015) presented that tourism is considered one of humanities and social sciences disciplines, so that the needed cognitive skills in tourism learning outcomes seen as problem solving, analytical, creative and applicative thinking. Online learning and training in tourism industry are used to update employees' business relations knowledge (Murphy et al., 2015). Maher (2004) and Betts (2008) proposed learning outcomes benefits as; putting student at the center of experienced knowledge, enhancing employability, and present open educational system. Accordingly, the present study suggests the following tourism learning outcomes hypothesis (Fig.1):

Hypothesis seven (H7): Tourism learning outcomes has a significant impact on tourism employability

Hypothesis seven (H7a): Future of technological innovation tools and platforms will positively moderate the influence of tourism learning outcomes on tourism employability and job competitiveness

Hypothesis seven (H7b): Future of traditional classroom tools and systems will not moderate the influence of tourism learning outcomes on tourism employability and job competitiveness

\section{Future of technological innovation versus traditional classroom}

Technological innovations are linking tourism internships with classroom learning; therefore it bridges the gap from classroom to workplace. Lack of adequate education and training as a priority issue affected quality of personnel and service in tourism (Pollock and Ritchie, 1990). Zagonari (2009) explained that balancing tourism education and training is needed for tourism graduates because it beneficial to all tourism stakeholders and in order to cope with changing skill requirements and rapid technological advances. The compatibility integration between tourism internship or training and traditional classroom learning has been used to ensure experience complement and enhance students' knowledge (Stansbie et al., 2016). Singh and Lee (2008) pointed out that ICTs tools can enhance effectiveness and efficiency in tourism training and education by mixing traditional classroom interactions with collaborative activity. Accordingly, ICTs virtual platforms become more pervasive with its unique tourism learning and training features and characteristics (Huang et al., 2013). Employment that linked to tourism education defines as knowledge, skills, and attitudes ability to adapt to professional needs and recent dynamics of new labor markets (Eurico et al., 2015). Zagonari (2009) stated that tourism employers in global market should be aware that there is a call for changing skill requirements due to rapidly technological advances. Stansbie et al., (2016) analyzed that result of tourism internships and classroom education combinations ensure learning of new skills and competencies. The internship mixed with prior theory learning in classroom develops new skills and enriches the needed employment qualifications. Generally, the high impacts of learning practice can be summarized as; development of problem solving and research skills, increase motivations, collaborative work assignments with peers, reflective learning practices, improved grades and academic performance (Stansbie et al., 2016). Recently; the research into internships 
within a hospitality and tourism management context are plentiful focused on student/ faculty outcomes from the internship experience itself, and explore the relationship between the theory delivered within a classroom context, and the experiential component obtained from internships. Students' preparations for being employable individuals have become major and critical elements in obtaining suitable employment (De Vos et al., 2011; Ruhanen et al., 2013; Stansbie et al., 2013; Lohman et al., 2015; Robinson et al., 2016; Stansbie and Nash, 2016).

According to many previous studies, there is a need for well-trained graduates in tourism complex industry (Eurico et al., 2015). Accordingly, present study suggests the following hypothesis regarding future of applying IT tools and platforms from one side comparing with using traditional classroom tools and systems in the other side (Fig.1):

Hypothesis eight (H8): Using innovation technology tools and platforms in the future has a positive impact on tourism learning outcomes

Hypothesis nine (H9): Using traditional classroom systems in the future has a negative impact on tourism learning outcomes

Hypothesis ten (H10): Using innovation technology tools and platforms in the future has a positive impact on tourism employability and job competitiveness

Hypothesis eleven (H11): Using traditional classroom systems in the future has a negative impact on tourism employability and job competitiveness

\section{Research Methodology \\ Community, Sampling and Methods}

This study concerns developing tourism education and learning methods using technological innovations. Its qualitative and quantitative methods limited only to both Egyptian tourism education staff (academic community staff) and tourism employees' point of view. The paradigm benchmarking from learning outcomes perspective methodology has been used among them. The purposes for choice of such sample are to obtain actual results and achieving optimum measurements for the current benchmarking and future guidelines. In Egypt there are many different tourism education programs, common ones being tourism public and private faculties and their tourism related departments, departments of tourism management in private academic institutes, vocational tourism schools or tourism and hotels schools under higher education umbrella. The present study measures tourism learning outcomes, knowledge and expertise generated by using innovation technology tools as study approach. SmartPLS-3.0 was used in the current study to analyze model structure and measurements. Conveniences simple random sample approach were used in collecting the survey data, as the actual data community is wide and unlimited; determining sample size regarding study population depends on many previous studies. krejcie and morgan (1970) identified that, if the population is more than 100.000 then the sample optimum size should be more than 385. Also, Tabachnick and Fidell (2007), Hair et al., (2006) identified the value of distributed forms or study sample should be counted regarding the number of its variables, not less than 300 or multiplication of study variables times eight then plus 50 (Number of Variables $\mathrm{x} 8+50$ ) for most of statistical analysis such as multiplier regression, factor analysis, structure equitation modelling (SEM). The data collection starts on November 25, 2016 till March 10, 2017. Generally, 650 questionnaires were distributed; with 540 valid respondents were received. $83 \%$ accounted response rate considerably accepted for the purposes of this study, and 110 respondents eliminated accounted (17\%) missing, late, or invalid to be included regarding incomplete responses or missing some variables. For ensuring validity, before administrating the final study questionnaire survey, a pilot test was conducted to assess 
and review the instrument reliability for content validity and to recognize any problems in understanding and operations. About identified 40 selected samples were used in the pilot study covered tourism education and academic staff in addition to employees graduates and nontourism graduates. The objectives of the pilot study are; estimate study significant, obtain feedback and comments that help in amend and modified questionnaire content notably add more details about used terms such as Bloom's Digital Taxonomy and Kolb's learning style, and reduce the risk and benefited the response community, rate and data analysis.

\section{Results and Findings}

\section{Descriptive Analysis of the Study Demographic Information}

The following table (1) shows study sample demographic information and variables. SPSS data analysis program V.21 statistics and Microsoft excel packages were used for data analysis. The age variable represented as; $19 \%$ in less than 29 year category, 34\% were from 30-39 years, $27 \%$

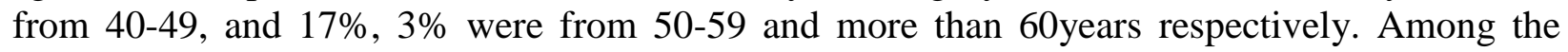
respondents gender, $53 \%$ were male and $47 \%$ were female.

Table 1: The study sample Demographic Profile and Variables

\begin{tabular}{|c|c|c|c|}
\hline Variables & & N.* & Percentage \\
\hline \multirow[t]{5}{*}{ Age } & - $\quad$ Less than 29 & 104 & $19 \%$ \\
\hline & - $\quad$ From 30-39 & 186 & $34 \%$ \\
\hline & - $\quad$ From 40-49 & 143 & $27 \%$ \\
\hline & - $\quad$ From 50-59 & 91 & $17 \%$ \\
\hline & - $\quad$ More than 60 years & 16 & $3 \%$ \\
\hline \multirow[t]{2}{*}{ Gender } & - Male & 284 & $53 \%$ \\
\hline & - Female & 256 & $47 \%$ \\
\hline \multirow{5}{*}{$\begin{array}{l}\text { Education } \\
\text { Qualifications }\end{array}$} & - $\quad$ Non-Tourism Education & 146 & $27 \%$ \\
\hline & - $\quad$ Tourism Vocational degree & 113 & $21 \%$ \\
\hline & - $\quad$ Tourism Bachelor's \& Diploma degree & 158 & $29 \%$ \\
\hline & - $\quad$ Master in Tourism & 44 & $8 \%$ \\
\hline & - Doctorate in Tourism & 79 & $15 \%$ \\
\hline \multirow{5}{*}{$\begin{array}{l}\text { Years of } \\
\text { Experiences }\end{array}$} & - Less than 4 & 132 & $24.5 \%$ \\
\hline & - $\quad$ From 5-14 & 132 & $24.5 \%$ \\
\hline & - $\quad$ From 15-24 & 148 & $27 \%$ \\
\hline & - $\quad$ From 25- 34 & 101 & $19 \%$ \\
\hline & - $\quad$ More than 35 Years & 27 & $5 \%$ \\
\hline \multirow{7}{*}{$\begin{array}{l}\text { Nature of } \\
\text { Employment }\end{array}$} & - $\quad$ Tourism Education & 110 & $21 \%$ \\
\hline & - $\quad$ Government in tourism sector & 76 & $14 \%$ \\
\hline & - $\quad$ Private in travel agents & 165 & $29 \%$ \\
\hline & - $\quad$ Private in Hospitality Sector & 81 & $15 \%$ \\
\hline & - $\quad$ Airport ground services \& Cabin Crew & 44 & $9 \%$ \\
\hline & - $\quad$ Tourism Marketing and Promotions & 40 & $7 \%$ \\
\hline & - $\quad$ Others in tourism & 24 & $5 \%$ \\
\hline \multirow{5}{*}{$\begin{array}{l}\text { Average time } \\
\text { durations per } \\
\text { day to use } \\
\text { internet }\end{array}$} & - $\quad$ Less Than 2 Hours & 43 & $8 \%$ \\
\hline & - $\quad$ Between 2-5 Hours & 265 & $49 \%$ \\
\hline & - $\quad$ Between 5-7 Hours & 170 & $31.5 \%$ \\
\hline & - $\quad$ Between 7-10 Hours & 62 & $11.5 \%$ \\
\hline & \multicolumn{3}{|l|}{$\mathrm{N}^{*}=$ Total Number $(540)=100 \%$} \\
\hline
\end{tabular}

The data concerns respondents education qualification variables shows that $27 \%$ were in nontourism education category, $21 \%$ tourism vocational education, $29 \%$ were in tourism Bachelor's \& Diploma degree category. $8 \%$ and $15 \%$ were in Master and Doctorate in tourism category, respectively. Description of demographic data shows respondents years of experiences as; 24.5 
were in less than 4 years and the same from 5-14 years, $27 \%$ were in from 15-24, and 19\% were in from 25-34 years. In addition, concerning the respondents' nature of employment data shows that $29 \%$ from the respondent's works in private travel agents, $21 \%$ in tourism education, $15 \%$ and $14 \%$ were in private hospitality sector and government tourism sector respectively. Most of respondents $49 \%$ enjoy between $2-5$ hours in average duration internet using per day, $31.5 \%$ between $5-7$ hours, and $11.5 \%$ between $7-10$ hours.

\section{Descriptive Study Model and latent Constructs Items}

The next table (2) shows the items used to estimate the study latent constructs. Statistics analysis for all study items and its descriptions hypothesis and relations shows the mean generated by the Likert scale 1 to 5 . The scale was used to measure and allow identifying how participants trust and believe in certain data items and descriptions in supporting the study model constructs, relations, and normality tests. Also, the study model figure (1) was analyzed using a global structure equation model (SEM) SmartPLS-3.0 (Ringle et al., 2015). The study items and subitems statistics descriptions can be stated as follow:

TIT $=$ Technological Innovation Tools

TIT1 = Electronic presentations \& Info graphics improve learning outcomes

TIT2= Video (conferencing) \& Jet Audio \& Sound Record improve learning outcomes

TIT3= Info Screen Cast Programs in YouTube improve learning performance

TIT4= Employing Interactive Google drive (Assessments, Training, Exams ...etc.) enhance tourism learning outcomes

TIT5= Employing Virtual learning \& Internet based courses positively improve the tourism learning outcomes

TIC $=$ Technological Innovation Characteristics

TIC1 $=$ Technological Innovations allow e-learning accessibility and accuracy experiences

TIC2 $=$ Technological Innovations enhance e- connectivity and diversity experiences

TIC3= Technological Innovations allow flexibility \& full design possibilities experiences

TIC4= Technological Innovations provide global interactivity and integrity experiences

TIC5= Technological Innovations provide low cost, save time, and distance experiences

RJT = Reasons and justifications of using Technological Innovation tools

RJT1 $=$ TI tools ensure learning active feedback and responses measurements

RJT2 $=$ TI tools eliminate traditional classroom time \& distance restrictions

RJT3= TI tools allow use multimedia interactive learning platforms

RJT4= TI tools develop human behavior, thinking, trends, and knowledge skills

$\mathrm{CMD}=$ Using $\mathrm{TI}$ tools in tourism curriculum mapping design measurements

CMD1 $=$ TI tools increase motivations and fulfill student's perceptions

CMD2 = TI tools improve academic performance, grades, and records

CMD3= Using E-portfolios will be more effective and valuable

CMD4= TI tools enrich collaborative work assignments with peers

$\mathrm{KLB}=$ Kolb's learning styles Modes in tourism education

KLB1= E-Learning will help feeling experiences and sharing knowledge

KLB2= E-Learning will help in watching and explain information process

KLB3= E-Learning enhances thinking and analysis research data methods

KLB4= E-Learning enhances doing data hypothesis to re-design solutions

BDT= Bloom's Digital Taxonomy and Web2.0 social media

BDT1= E-Learning helps remembering basic knowledge and facts 
BDT2=E-Learning help in understanding and describing detailed relations

BDT3= E-Learning help in applying tourism business procedures

BDT4= E-Learning helps analyzing business parts relations in total structure

BDT5= E-Learning allows assessment by standards

BDT6= E-Learning allows creating new tourism complex and structure

$\mathrm{TEC}=$ Tourism employability and job competitiveness

$\mathrm{TEC} 1=\mathrm{TI}$ tools enriches carrier advices, practices and competencies

TEC2 $=$ Facilitates providing well-defined actual tourism carrier paths

TEC3 = Increases tourism global experiences, carrier intension, and preparations

TEC4 $=$ Decreases gap issues linking tourism education with employability

$\mathrm{TLO}=$ Tourism learning Outcomes

TLO1= It helps having an understanding of tourism theory and practice research

$\mathrm{TLO} 2=$ It helps fostering practice technological systems skills for employability

TLO3 $=$ It increases ability to analysis or discuss impacts of tourism on business

TLO4= It help in understanding the role of government and private sectors

TLO5= Increases ability to practice effective marketing sales techniques

TLO6= Apply human resource management techniques and skills

TLO7= Increase ability to analyses and encountering new challenges and crisis

IRT= Future of Innovative technology tools and platforms

IRT1 $=$ TI tools positively affects tourism learning outcomes

IRT2 $=$ TI tools positively affects tourism jobs and employability

TRT $=$ Future of Traditional classroom tools and systems

TRT1 $=$ Traditional classroom tools negatively affects tourism learning outcomes

TRT2 $=$ Traditional classroom tools negatively affects tourism jobs and employability

Using SEM SmartPLS-3 measures the psychometric properties of the measurement model, and assessments parameters of the structural model. This tool allows the instantaneous analysis of intensive indicator variables, allowing measurement of widespread relations between moderator and latent variable indicators (Chin, 2010; Al-Gahtani et al., 2007). Therefore, the study reported standard deviations, Item-Total correlation that measure the correlations between items within each variable, excess Kurtosis has reported to measure data relatively to normal distribution, it describes a probability or return distribution to ensure that the coefficient associated with a normal distribution, and Skewness to measure statistics items and descriptions data symmetry, and ensure that study data looks the same to the left and right of the center point. In addition, data analysis experimented that the standard error of mean for all the study items and descriptions was less than 0.029 to increase data validity.

Table 2: Descriptive model constructs measurement and normality distributions tests

\begin{tabular}{|c|c|c|c|c|c|}
\hline Statistics Items/ Descriptions & $\begin{array}{c}\text { Mean } \\
*\end{array}$ & $\begin{array}{c}\text { SD } \\
* *\end{array}$ & $\begin{array}{c}\text { Item-Total } \\
\text { Correlation }\end{array}$ & $\begin{array}{c}\text { Excess } \\
\text { Kurtosis }\end{array}$ & $\begin{array}{c}\text { Skewness } \\
\text { Item }\end{array}$ \\
\hline TIT: Technological Innovation Tools \\
\hline TIT1 & 4.5 & 0.75 & 0.753 & 0.527 & -0.703 \\
\hline TIT2 & 4.5 & 0.76 & 0.686 & 0.438 & -0.672 \\
\hline TIT3 & 4.2 & 0.86 & 0.724 & 0.653 & -0.607 \\
\hline TIT4 & 4.1 & 0.95 & 0.677 & 0.674 & -0.483 \\
\hline TIT5 & 4.2 & 0.99 & 0.795 & 0.694 & -0.672 \\
\hline
\end{tabular}


International Journal of Heritage, Tourism and Hospitality Vol. (11), No. (3/2)

Special issue on papers of the $10^{\text {th }}$ ICTH (2017) organized by Faculty of Tourism and Hotels, Fayoum University

TIC: Technological Innovation Characteristics

\begin{tabular}{|c|c|c|c|c|c|}
\hline TIC1 & 4.6 & 0.65 & 0.825 & 0.682 & -0.574 \\
\hline TIC2 & 4.6 & 0.69 & 0.794 & 0.813 & -0.674 \\
\hline TIC3 & 4.4 & 0.74 & 0.786 & 0.736 & -0.485 \\
\hline TIC4 & 4.2 & 0.77 & 0.839 & 0.693 & -0.579 \\
\hline TIC5 & 3.9 & 0.97 & 0.764 & 0.636 & -0.630 \\
\hline RJT1 & 4.5 & 0.72 & 0.793 & 0.726 & -0.430 \\
\hline RJT: Reasons and justifications of using Techlogical Innovation tools \\
\hline RJT3 & 4.4 & 0.73 & 0.815 & 0.814 & -0.520 \\
\hline RJT4 & 4.3 & 0.78 & 0.768 & 0.591 & -0.763 \\
\hline & 4.2 & 0.67 & 0.753 & 0.497 & -0.685 \\
\hline
\end{tabular}

RJT: Reasons and justifications of using Technological Innovation tools

CMD: Using TI tools in tourism curriculum mapping design measurements

\begin{tabular}{|c|c|c|c|c|c|}
\hline CMD1 & 4.5 & 0.58 & 0.686 & 0.745 & -0.568 \\
\hline CMD2 & 3.9 & 0.58 & 0.677 & 0.682 & -0.549 \\
\hline CMD3 & 3.7 & 0.56 & 0.753 & 0.736 & -0.627 \\
\hline CMD4 & 4.5 & 0.65 & 0.753 & 0.811 & -0.431 \\
\hline
\end{tabular}

KLB: Kolb's learning styles Modes in tourism education

\begin{tabular}{|c|c|c|c|c|c|}
\hline KLB1 & 4.4 & 0.57 & 0.840 & 0.562 & -0.673 \\
\hline KLB2 & 4.2 & 0.57 & 0.796 & 0.489 & -0.780 \\
\hline KLB3 & 3.9 & 0.63 & 0.732 & 0.725 & -0.440 \\
\hline KLB4 & 3.6 & 0.66 & 0.803 & 0.452 & -0.594 \\
\hline
\end{tabular}

BDT: Bloom's Digital Taxonomy and Web2.0 social media

\begin{tabular}{|c|c|c|c|c|c|}
\hline BDT1 & 4.6 & 0.57 & 0.780 & 0.561 & -0.630 \\
\hline BDT2 & 4.5 & 0.61 & 0.820 & 0.409 & -0.531 \\
\hline BDT3 & 4.3 & 0.61 & 0.739 & 0.572 & -0.484 \\
\hline BDT4 & 3.8 & 0.63 & 0.823 & 0.635 & -0.610 \\
\hline BDT5 & 4.1 & 638 & 0.693 & 0.692 & -0.783 \\
\hline BDT6 & 3.7 & 0.64 & 0.823 & 0.710 & -0.490 \\
\hline
\end{tabular}

TEC: Tourism employability and job competitiveness

\begin{tabular}{|c|c|c|c|c|c|}
\hline TEC1 & 4.1 & 0.63 & 0.680 & 0.753 & -0.613 \\
\hline TEC2 & 4.2 & 0.61 & 0.783 & 0.682 & -0.493 \\
\hline TEC3 & 4.2 & 0.65 & 0.643 & 0.733 & -0.683 \\
\hline TEC4 & 3.9 & 0.64 & 0.736 & 0.527 & -0.635 \\
\hline
\end{tabular}

TLO: Tourism learning Outcomes

\begin{tabular}{|c|c|c|c|c|c|}
\hline TLO1 & 4.5 & 0.61 & 0.793 & 0.453 & -0.574 \\
\hline TLO2 & 4.2 & 0.61 & 0.691 & 0.873 & -0.504 \\
\hline TLO3 & 4.3 & 0.61 & 0.862 & 0.627 & -0.629 \\
\hline TLO4 & 4.1 & 0.63 & 0.658 & 0.592 & -0.596 \\
\hline TLO5 & 3.9 & 0.71 & 0.874 & 0.460 & -0.764 \\
\hline TLO6 & 4.2 & 0.68 & 0.759 & 0.633 & -0.483 \\
\hline TLO7 & 3.6 & 0.96 & 0.748 & 0.725 & -0.560 \\
\hline IRT1 tools and platforms \\
\hline IRT: Future of Innovative technology tro \\
\hline IRT2 & 4.5 & 0.85 & 0.853 & 0.572 & -0.683 \\
\hline TRT: Future of Traditional classroom tools and systems & 0.793 & 0.743 & -0.480 \\
\hline
\end{tabular}


International Journal of Heritage, Tourism and Hospitality Vol. (11), No. (3/2)

Special issue on papers of the $10^{\text {th }}$ ICTH (2017) organized by Faculty of Tourism and Hotels, Fayoum University

\begin{tabular}{|c|c|c|c|c|c|}
\hline TRT1 & 3.7 & 0.78 & 0.753 & 0.736 & -0.528 \\
\hline TRT2 & 3.9 & 0.82 & 0.753 & 0.736 & -0.593 \\
\hline $\begin{array}{l}\text { *The 5-point Likert Scale: 1 = strongly disagree, 2=disagree, 3 = neutral, 4=agree and 5 = strongly agree, } \\
\text { **SD= Standard Deviations }\end{array}$ \\
\hline
\end{tabular}

\section{Assessment of the measurement construct model}

SmartPLS-SEM was used in study measurements, shifting to the data results of convergent validity was recognized by investigating factor loadings (FL), composite reliability (VR), in addition to average variance extracted (AVE) measurements, and Cronbach's alpha ( $\alpha$ ) for study models was analyzed and given in Table (3) (Hair et al., 2006). Interestingly, it can be confirmed according to the illustrated results in table (3) that all factor loadings exceeded the stander value of 0.600. It was also reported that the measurements are strong enough in light of the construct indicators of internal consistency reliability as shown in the CR column. The composite reliability data of the different construct model denoted that CR measures range from 0.852 to 0.975 confirmed that it exceed the recommended threshold value of 0.700 so it was greater than the common.

Table 3: Factor Loadings and Reliability Measurements of Study Models

\begin{tabular}{|l|c|c|c|c|}
\hline Model: Study Indicators/ Variables & $\begin{array}{c}\text { Factor } \\
\text { Loadings } \\
(\mathrm{FL})\end{array}$ & $\begin{array}{c}\mathrm{CR} * \\
(<0,800)\end{array}$ & $\begin{array}{c}(\mathrm{CA} \alpha)^{*} \\
(<0,70)\end{array}$ & $\begin{array}{c}\text { AVE** } \\
(<0,6)\end{array}$ \\
\hline Technological Innovation Tools & 0.973 & 0.918 & 0.91 & 0.69 \\
\hline TIT1 & 0.965 & & & \\
\hline TIT2 & 0.921 & & & \\
\hline TIT3 & 0.875 & & & \\
\hline TIT4 & 0.932 & & & 0.78 \\
\hline TIT5 & 0.918 & & & \\
\hline Technological Innovation Characteristics & 0.869 & & & \\
\hline TIC1 & 0.956 & & & \\
\hline TIC2 & 0.950 & & & \\
\hline TIC3 & 0.873 & & & \\
\hline TIC4 & 0.956 & & & \\
\hline TIC5 & 0.982 & & & \\
\hline Reasons of using TI tools & 0.957 & & & \\
\hline RJT1 & 0.961 & & & \\
\hline RJT2 & & & \\
\hline RJT3 & & & \\
\hline RJT4 & & & \\
\hline $\begin{array}{l}\text { Using TI tools in tourism curriculum } \\
\text { measurements }\end{array}$ & 0.943 & & \\
\hline CMD1 & 0.916 & & & \\
\hline CMD2 & 0.894 & & & \\
\hline CMD3 & 0.875 & & & \\
\hline CMD4 & 0.931 & & & \\
\hline Kolb's learning styles modes & 0.917 & & & \\
\hline KLB1 & 0.896 & & & \\
\hline KLB2 & 0.925 & & & \\
\hline KLB3 KLB4 & 0.964 & & & \\
\hline Bloom's Digital Taxonomy and Web2.0 social media & & \\
\hline BDT1 & & & \\
\hline
\end{tabular}


International Journal of Heritage, Tourism and Hospitality Vol. (11), No. (3/2)

Special issue on papers of the $10^{\text {th }}$ ICTH (2017) organized by Faculty of Tourism and Hotels, Fayoum University

\begin{tabular}{|c|c|c|c|c|}
\hline Model: Study Indicators/Variables & $\begin{array}{l}\text { Factor } \\
\text { Loadings } \\
\text { (FL) }\end{array}$ & $\begin{array}{c}\text { CR** } \\
(<0,800)\end{array}$ & $\begin{array}{l}(\mathrm{CA} \alpha)^{*} \\
(<0,70)\end{array}$ & $\begin{array}{c}\mathrm{AVE}^{* *} \\
(<0,6)\end{array}$ \\
\hline BDT 2 & 0.795 & & & \\
\hline BDT 3 & 0.874 & & & \\
\hline BDT4 & 0.916 & & & \\
\hline BDT 5 & 0.942 & & & \\
\hline BDT6 & 0.894 & & & \\
\hline \multicolumn{2}{|c|}{ Using TI tools in employability competitiveness } & 0.864 & 0.89 & 0.63 \\
\hline TEC1 & 0.973 & & & \\
\hline TEC2 2 & 0.958 & & & \\
\hline TEC3 & 0.869 & & & \\
\hline TEC4 & 0.817 & & & \\
\hline \multicolumn{2}{|l|}{ Tourism learning Outcomes } & 0.956 & 0.80 & 0.76 \\
\hline TLO1 & 0.950 & & & \\
\hline TLO2 & 0.963 & & & \\
\hline TLO3 & 0.872 & & & \\
\hline TLO4 & 0.936 & & & \\
\hline TLO5 & 0.884 & & & \\
\hline TLO6 & 0.932 & & & \\
\hline TLO7 & 0.893 & & & \\
\hline \multicolumn{2}{|c|}{ Future of Innovative technology tools and platforms } & 0.975 & 0.85 & 0.81 \\
\hline $\begin{array}{ll}\text { IRT1 } \\
\text { IRT2 }\end{array}$ & 0.914 & & & \\
\hline IRT2 & 0.953 & & & \\
\hline \multicolumn{2}{|c|}{ Future of Traditional classroom tools and systems } & 0.914 & 0.91 & 0.67 \\
\hline $\begin{array}{ll}\text { TRT1 } \\
\text { TRT2 }\end{array}$ & 0.896 & & & \\
\hline
\end{tabular}

* Cronbach's Alpha $(\mathrm{CA} \alpha)$ used to assessing validity and reliability, AVE: Average Variance

Extracted. CR: Composite Reliability, **All estimated indices above threshold of 0.600 for CR and $\cap 5 \cap \cap$ for $\Delta \mathrm{V} / \mathrm{F}$

The current study analysis includes measuring Cronbach's alpha reliability coefficient to clarify psychometric properties of measurement model. The obtained results (Table,3) concerning indicator and construct reliability revealed that Cronbach's alpha values for all measures exceeds recommended threshold value of 0.700 , so that all measures are strong enough in light of indicators reliability (Hair et al., 2011). also, AVE reflects total amount of variance in the indicators accounted by the latent construct, the obtained results clarified that the AVE for each latent construct measure exceed 0.500 values that confirmed robust of the measurement as referring to Fornell and Larker (1981) and Hair et al., (2006) guidelines, so that results support the model convergent validity. Finally, obtained results are in harmony with guidelines detected by Ringle et al., (2015); Chin, (1998); Bagozzi and Yi (1988); Hair et al., (2006); and Nunnally (1978) putting a common category pointed out that both item loadings and AVE for each construct should exceed 0.500 .

\section{Discriminant validity for the study latent variable constructs}

Testing the inter-correlations between the study variable constructs is demonstrated in table (4) where square roots of average variance extracted (AVEs) values are on the diagonal of the matrix. The results of tested discriminant validity of variable constructs reported that all study tested variable constructs strongly greater in all inter-correlations than the cut-off diagonal of the matrix in both vertical row and horizontal column. The results of the study recorded more than 
0.500 as it is between 0.690 and 0.947 values, so that the results supporting establishing the discriminant validity of the study latent variable construct scales.

Table (4): Discriminant validity for the study variable constructs.

\begin{tabular}{|c|c|c|c|c|c|c|c|c|c|c|}
\hline Construct* & TIT & TIC & RJT & CMD & KLB & BDT & TEC & TLO & IRT & TRT \\
\hline TIT & $\underline{0.794}$ & & & & & & & & & \\
\hline TIC & 0.536 & $\underline{0.816}$ & & & & & & & & \\
\hline RJT & 0.340 & 0.635 & 0.947 & & & & & & & \\
\hline CMD & 0.528 & 0.494 & 0.698 & $\underline{0.780}$ & & & & & & \\
\hline KLB & 0.546 & 0.652 & 0.432 & 0.783 & $\underline{0.842}$ & & & & & \\
\hline BDT & 0.508 & 0.356 & 0.381 & 0.625 & 0.558 & $0 . \underline{690}$ & & & & \\
\hline TEC & 0.364 & 0.374 & 0.463 & 0.537 & 0.582 & 0.615 & $\underline{0.796}$ & & & \\
\hline TLO & 0.483 & 0.625 & 0.418 & 0.582 & 0.541 & 0.536 & 0.607 & 0.793 & & \\
\hline IRT & 0.395 & 0.574 & 0.562 & 0.463 & 0.429 & 0.471 & 0.452 & 0.637 & $\underline{0.865}$ & \\
\hline TRT & 0.462 & 0.723 & 0.463 & 0.436 & 0.587 & 0.539 & 0.431 & 0.449 & $\overline{0.753}$ & 0.853 \\
\hline
\end{tabular}

*Comparing square root of AVEs values for each construct with correlations and other constructs are on the diagonal of the matrix (Bold and underlined)

\section{Factor Loadings and Cross-Loadings of Measurement Constructs}

The study using PLS-Graph on measures convergent validity test. The extracting factors loadings and cross loadings of all the study indicator items to their respective latent constructs was highlighted in table (5). It was assured the discriminant validity for the study measurement constructs. The loadings on their relevant constructs are shadowed. The mechanism can be analyzed by correlating the component scores of each latent variable with both their respective block of indicators and all other items that are included in the model, or from a lower value of 0.800 to an upper value of 0.963 . Therefore, it can be noted that each item loads higher on its significant construct than on any other construct both when browsing a cross the rows or down the column. It also noted that, all the tested item's factor loading on its respective construct was highly significant $(p<0.0001)$ as it recorded $(0.000)$ as indicated by the $T$-statistics of the outer model loadings in the PLS-Graph output. The highly significant $T$-statistic for each individual item loading both confirm convergent validity of these indicators as representing distinct latent constructs. Summarily, results proved confidence that the measures test appropriate. Finally, it can be confirmed that all the analysis depends on PLS-Handbook by Vinzi et al., (2010).

\section{The Structural Model and Results of Hypothesis Testing}

This part concerns the obtained findings and results of the proposed hypothesis in the study structural models. The Figure (3) interacting simple indicator approach describes results of all tested direct and moderator variables. The path coefficients $(\beta)$ are assessed by means of a regular regression between projected latent variable scores in harmony with specified network of structural relations, and to facilitate formative and reflective empirical modeling. Results illustrated positive for all model beta path coefficients. It showed significantly relationships at (P $<0.0001)$. It can be expressed that the study path model comprised of eleven latent variables, including the endogenous variable, so that the study simple moderating effect include all components that entered into the regression function explicitly. The three-way interaction all single and two-way interaction effects included. The revealed structural equation model analysis supported results in positively significant, negatively significant, moderate, and not moderate hypothesis as following: H1: Using technological innovation tools has a positively significant 
effect on tourism learning outcomes (supported $\mathrm{H} 1: \beta=0.20$ and $P=0.000$ ). H2: Applying technological innovation characteristics significant positive enhance tourism learning outcomes (supported $\mathrm{H} 2$ : $\beta=0.23$ and $P=0.000$ ). H3: Reasons of using technological innovation tools has a positive significant impact on tourism learning outcomes (supported $\mathrm{H} 3$ : $\beta=0.39$ and $P=$ 0.000). H4: Using TI tools in curriculum mapping design measurements have a positive significant impact on tourism learning outcomes (supported H4: $\beta=0.30$ and $P=0.000$ ). H5: Using modified Kolb's learning styles modes had a positive significant enhance on tourism learning outcomes (supported H5: $\beta=0.53$ and $P=0.000$ ). H6: Using Bloom's DT and Web2.0 social media had a positive significant enhance on tourism learning outcomes (supported H6: $\beta=$ 0.31 and $P=0.000$ ).

Figure 3: Path estimates based on PLS structural model results

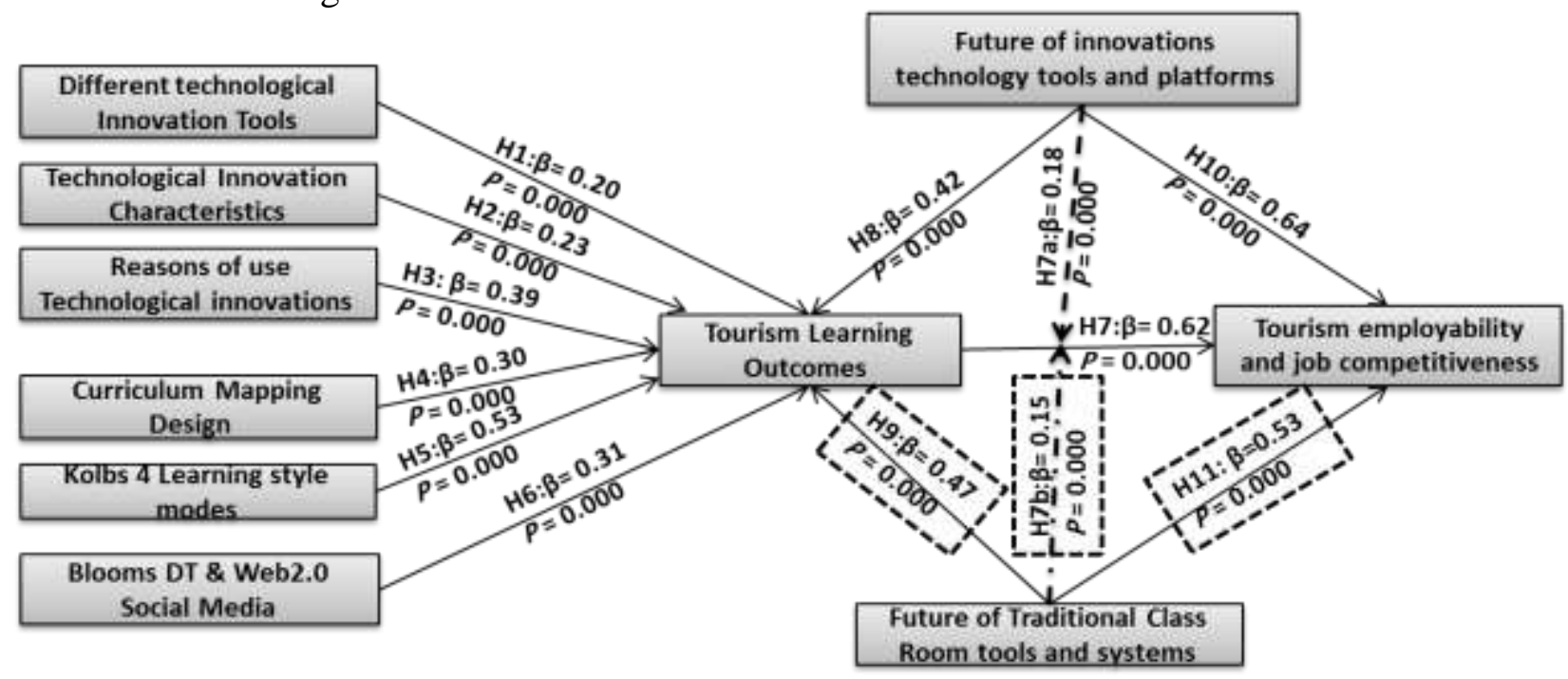

All the tested hypothesis supported positive relationships except $\mathrm{H} 7 \mathrm{~b}, \mathrm{H} 11$ and $\mathrm{H} 9$ supported negative relationships

Denotes significance of $(P=0.000)$

H7: Tourism learning outcomes has a significant impact on tourism employability and job competitiveness (supported $\mathrm{H} 7: \beta=0.62$ and $P=0.000$ ). H7a: future of technological innovation tools positively moderate the influence of learning outcomes on tourism employability and job competitiveness (supported H7a: $\beta=0.18$ and $P=0.000$ ). $\mathrm{H} 7 \mathrm{~b}$ : future of traditional classroom not moderate the influence of learning outcomes on tourism employability and job competitiveness (supported $\mathrm{H} 7 \mathrm{~b}: \beta=0.15$ and $P=0.000$ ). H8: Using innovation technology tools in the future has a positive impact on tourism learning outcomes (supported H8: $\beta=0.42$ and $P=$ 0.000). H9: Using traditional classroom tools and systems in the future has a negative impact on tourism learning outcomes (supported H9: $\beta=0.47$ and $P=0.000$ ). H10: Using innovation technology tools in the future has a positive impact on tourism employability and job competitiveness (supported H10: $\beta=0.64$ and $P=0.000$ ). H11: Using traditional classroom tools in the future has a negative impact on tourism employability and job competitiveness (supported H11: $\beta=0.53$ and $P=0.000$ ). 
International Journal of Heritage, Tourism and Hospitality Vol. (11), No. (3/2)

Special issue on papers of the $10^{\text {th }}$ ICTH (2017) organized by Faculty of Tourism and Hotels, Fayoum University

Table (5): PLS Factor Loadings and Cross-Loadings of Measurement Constructs

\begin{tabular}{|c|c|c|c|c|c|c|c|c|c|c|c|}
\hline$*$ & TIT & TIC & $\mathrm{RJ}]$ & CMD & KLB & BDT & TEC & TLO & IRT & TRT & $\underset{* *}{V \text { alue }}$ \\
\hline TIT1 & .882 & .253 & . 193 & .166 & .174 & .311 & .423 & .360 & .352 & .226 & $0.00 \mathrm{C}$ \\
\hline IT2 & .914 & .247 & .312 & .251 & .352 & .251 & .415 & .431 & .143 & .416 & 0.000 \\
\hline & .834 & .152 & .186 & .274 & .421 & .296 & .273 & .294 & .465 & .314 & 0.000 \\
\hline IT4 & .856 & .314 & .316 & .311 & .364 & .412 & .326 & .158 & .276 & .246 & 0.000 \\
\hline TIT5 & .942 & .114 & .154 & .418 & .137 & .326 & .237 & .226 & .126 & .258 & 0.000 \\
\hline TIC1 & .196 & .936 & .317 & .067 & .325 & .233 & .436 & .375 & .435 & .356 & 0.000 \\
\hline TIC2 & .215 & .856 & .224 & .350 & .417 & .316 & .325 & .312 & .329 & .324 & 0.000 \\
\hline TIC3 & .346 & .873 & .127 & .197 & .254 & .275 & .419 & .115 & .417 & .276 & .000 \\
\hline TIC4 & .239 & .915 & .315 & .365 & .364 & .423 & .321 & .371 & .414 & .436 & 0.000 \\
\hline TIC5 & .315 & .864 & .292 & .274 & .447 & .416 & .382 & .352 & .351 & .177 & .000 \\
\hline RJT1 & .187 & .265 & .875 & .151 & .271 & .235 & .271 & .073 & .316 & .419 & .000 \\
\hline JT2 & .269 & .096 & .892 & .325 & 197 & .314 & .344 & .491 & .321 & .367 & .000 \\
\hline & .358 & .153 & .914 & .265 & .364 & .441 & .251 & .374 & .384 & .341 & .000 \\
\hline JT4 & .338 & .271 & .823 & .141 & .075 & .205 & .362 & .325 & .263 & .427 & 0.000 \\
\hline CMD1 & .054 & .263 & .153 & .839 & .426 & .236 & .215 & .274 & .188 & .325 & .000 \\
\hline CMD2 & .175 & .142 & .316 & .881 & .315 & .318 & .347 & .342 & .254 & .362 & .000 \\
\hline CMD3 & .362 & .215 & .128 & 902 & .274 & .219 & .219 & .158 & .372 & .315 & 0.000 \\
\hline MD4 & .176 & .426 & .113 & .864 & .165 & .385 & .341 & .112 & .265 & .362 & 0.000 \\
\hline $\mathrm{B} 1$ & .352 & .157 & .274 & .183 & .843 & .381 & .452 & .367 & .429 & .214 & 0.000 \\
\hline B2 & .294 & .243 & .172 & .287 & .822 & .374 & .234 & .219 & .374 & .345 & 0.000 \\
\hline B3 & .319 & .251 & .384 & .315 & .925 & .115 & .178 & .418 & .116 & .311 & 0.000 \\
\hline LB4 & .157 & .176 & .115 & .347 & .847 & .254 & .036 & .327 & .326 & .251 & 0.000 \\
\hline DT1 & .231 & .165 & .163 & .361 & .254 & .862 & .187 & .371 & .158 & .384 & .000 \\
\hline DT2 & .341 & .272 & .351 & .302 & .217 & .914 & .256 & .403 & .421 & .427 & .000 \\
\hline T3 & .419 & .194 & .314 & .125 & .156 & .871 & .217 & .397 & .391 & .354 & 0.000 \\
\hline & .079 & .176 & .163 & .362 & .403 & .854 & .245 & .175 & .247 & .265 & .000 \\
\hline T5 & .326 & .193 & .218 & .294 & .342 & .918 & .231 & .384 & .416 & .119 & 0.000 \\
\hline T6 & .572 & .201 & .095 & .376 & .314 & .873 & .351 & .078 & .174 & .364 & 0.000 \\
\hline TEC1 & .3 & .241 & .211 & .354 & .273 & .247 & .856 & .414 & .158 & .273 & 0.000 \\
\hline TEC2 & .439 & .162 & .162 & .231 & .164 & .334 & .872 & .294 & .167 & .412 & 0.000 \\
\hline TEC3 & .217 & .133 & .371 & .256 & .417 & .412 & .893 & .336 & .421 & .375 & .000 \\
\hline TEC4 & .456 & .275 & .153 & .274 & .428 & .345 & .845 & .245 & .352 & .297 & 0.000 \\
\hline $\mathrm{O} 1$ & .128 & .141 & .189 & .311 & .156 & .143 & .341 & .823 & .314 & .355 & 0.000 \\
\hline & .417 & .215 & .224 & .342 & .24 & $.46^{\circ}$ & .377 & .911 & .285 & .281 & 0.000 \\
\hline & .324 & .362 & .273 & .173 & .147 & .337 & .351 & .874 & .409 & .353 & 0.000 \\
\hline & 237 & .243 & .122 & .251 & .352 & .345 & .254 & .821 & .371 & .241 & 0.000 \\
\hline TLO5 & .315 & .117 & .314 & .146 & .316 & .264 & .362 & .892 & .413 & .369 & 0.000 \\
\hline TLO6 & .063 & .238 & .217 & .275 & .342 & .371 & .357 & .884 & .265 & .320 & 0.000 \\
\hline TLO7 & .415 & .146 & .286 & .361 & & .365 & .342 & .841 & .271 & .315 & 0.000 \\
\hline IRT1 & & .327 & .245 & .254 & & .317 & .415 & & .944 & .253 & 0.000 \\
\hline & & .242 & .164 & .265 & & .146 & .246 & .38 & .873 & .382 & 0.000 \\
\hline & .125 & .136 & .321 & .154 & .114 & .319 & .375 & .432 & 368 & .910 & 0.000 \\
\hline TRT2 & .347 & .144 & .316 & .351 & .128 & .375 & .337 & .411 & .419 & .963 & 0.000 \\
\hline
\end{tabular}

\section{Discussion}

This study was listed in the field of tourism education and training. It measures the effects of using technological innovations on developing tourism education and learning methods from tourism learning outcomes perspective for tourism employability. The obtained results are in harmony with those detected by Songkram et al., (2015) who demonstrated that tourism e- 
learning combines benefit of classroom and online learning in content delivery, activities, measurements and evaluations. Theoretical implication in this study confirmed that ensuring tourism e-education and training considered the most important mechanism in enhancing tourism learning outcomes and employability competencies. Furthermore, technological constructivism, and learning style theories such as Bloom's Digital Taxonomy and Kolb's learning styles modes positively influenced the progress in tourism education environments and learning methods. The study construct consists of ten main indicators; it consists of forty four sub-items. The study using mixed theoretical and empirically frameworks. The results confirmed the tested paradigm and relationships. According to the structural model and results of tested hypothesis; the entire hypothesis $\mathrm{H} 1$ to $\mathrm{H} 11$, in addition to $\mathrm{H} 7 \mathrm{a}$ and $\mathrm{H} 7 \mathrm{~b}$ were certificating and supporting study model construct framework. All the study construct variables measures positive relationships except H7b, H9, H11 where the study model measures negative relationships.

Accordingly, the study practical implication found that innovation technology tools had a positive effect on tourism learning outcomes. Also, using TI characteristics, justifications, and using TI tools in tourism curriculum mapping design measurements had a positive significant effect on tourism learning outcomes. The study presented Kolb's learning styles modified modes in tourism education. The study findings confirmed positive interaction between modified Kolb's learning styles and tourism learning outcomes. The study recognized strong relationships between using Bloom's Digital Taxonomy and Web2.0 social media in tourism e-learning regarding tourism learning outcomes, so that Web2.0 social media effectively applied to tourism higher education. The current study focuses on analyzing tourism employability competitiveness variables as both direct and moderating variables. Results supported negative interactions between using traditional classroom tools and systems in the future and tourism learning outcomes, and tourism jobs and employability competitiveness. Results also recorded negative effects and not moderate the influence of learning outcomes on tourism employability and job competitiveness. Applying the same tests, it was shown that using innovation technology tools and platforms showed strong positive and significant relationships with; tourism learning outcomes, tourism employability and job competitiveness, and as a moderator indicates a strong relationship between learning outcomes and tourism employability and job competitiveness.

Figure 4: The links of study Complex Paradigm Shift in Tourism e-learning

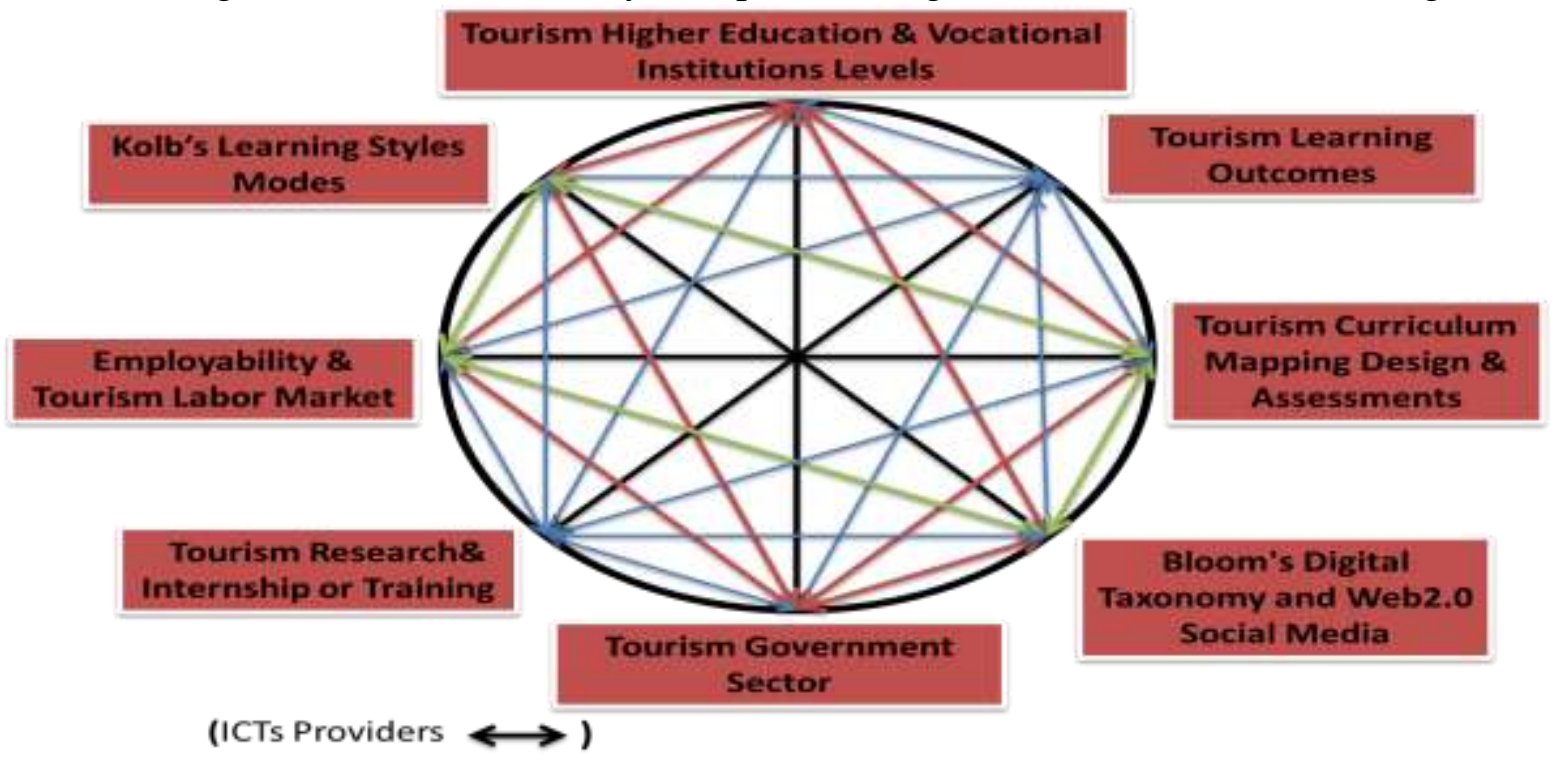


The current study examines putting complex paradigm shift from learning outcomes perspective of tourism e-learning and other linked elements Figure (4). The proposed resulted paradigm shift identifies nested and integrated network operators. It contains eight interrelated main linked items. First, tourism higher education and vocational institutions as a place that teaches and trains tourism courses until certificate is awarded for graduates. Second, tourism learning outcomes that previously identified to include graduates' knowledge, experiences, and skills. Third, it concerns curriculum mapping design and assessment in tourism learning and training. Fourth, Bloom's Digital Taxonomy and Web2.0 social media applications developed the tourism learning process. Fifth, concerns tourism official government sectors or authorities in its relations with other items in the paradigm. Sixth, tourism research and internship sector that driving tourism high quality HR criterion. Seventh, employability and tourism labor market. It relates to private sector that generates jobs and labor markets to ensure high quality needed HR. Eighth, Kolb's learning styles mode that helps in diversified new tourism experiential learning by using technological innovations. It can be noted that the whole complex paradigm measurements should be enhanced by ICTs links.

\section{Conclusions, Limitations and Future Studies}

E-learning is recognized as higher education fast growing market improves overall learning outcomes. It enriched the needed knowledge, experiences and practical skills in the tourism employment fields. The study empirically and theoretically employed effects of using technological innovations on developing tourism learning methods. Using TI tools in education for tourism employability competitiveness because it drive practices and competence, defined actual tourism carrier paths, and decrease gap issues linking tourism education with employability. There are great relationships between using TI and tourism learning programs outcomes; helps understanding tourism theory and practice, helps technological systems practice skills, increases ability to analysis and discuss impacts of tourism, enhances understanding the role of tourism government and private sectors, increases ability to practice effective marketing sales techniques, apply human resource management techniques and skills, and increase ability to analyses and encountering new challenges and crisis. The study limitations can be summarized in all Egyptian tourism learning providers from higher education in to the vocational educations in tourism institutes and schools. Also, the study sample size excluding the tourism student's point of view to avoid any elements affecting their opinions and to foster subjectivity. The study limited only to both tourism education staff (academic community staff in Egypt) and tourism employees' (included both tourism graduates and non-tourism graduates) point of views. Therefore, new studies concerning selected tourism programs, courses, students, and levels case studies and comparative analysis should be practically investigated to measure benefited of tourism e-learning tools, opportunities, and challenges in the coming researches in the future. Also, all bilateral relations and links in the current study complex paradigm shift should be studied separately in tourism e-learning in the future.

\section{References}

Abbas, T.M., Jones, E., and Hussien, F.M. (2016). Technological Factors Influencing University Tourism and Hospitality Students' Intention to Use E-Learning: A Comparative Analysis of Egypt and the United Kingdom, Journal of Tourism and Hospitality Education, 28 (4), 189-120. 
Adukaitea, A., Zylb, I., and Cantonia, L. (2016). Critical Perspectives: The role of digital technology in tourism education: A case study of South African secondary schools, Journal of Hospitality, Leisure, Sport and Tourism Education, 19, 54-65.

Afifi, G.M.H. (2011). E-learning as an alternative strategy for tourism higher education in Egypt, Quality Assurance in Education, 19 (4), 357-374.

Al-Gahtani. S.S., Hubona, G.S., and Wang, J., (2007). Information technology (IT) in Saudi Arabia: Culture and the acceptance and use of IT, Information \& Management, 44, 681691.

Alhajri, R., Al-Sharhan, S., and Al-Hunaiyyan, A., (2017). Perceptions and challenges of mobile learning: Case Study in Kuwait, International Journal of Social, Behavioral, Educational, Economic, Business and Industrial Engineering, 11 (2), 319-322.

Ally, M. (2004). Foundations of educational theory for online learning. In Terry (Ed.) The theory and practice of online learning (3-31), $2^{\text {nd }}$ edition, Athabasca, AB: Athabasca University.

Anderson, L.W., and Krathworthl, D.R. (2001). A taxonomy for learning, teaching and assisting: A revision of Bloom's taxonomy of education objectives. New York: Longman.

Bagozzi, R. P., and Yi, Y. (1988). On the evaluation of structural equation models, Journal of the Academy of Marketing Science, 16, 74-94.

Baker, L., Caldicott, J., and Spowart, J. (2011). Cooperative and work-integrated education in hospitality and tourism. In Coll, R.K. and Zegwaard K.E. (eds.), International handbook for cooperative and work-integrated education: international perspectives of theory research and practice, $2^{\text {nd }}$ edition. Lowell, MA: World Association for Cooperative Education, 219-228.

Betts, S.C. (2008). Teaching and Assessing Basic Concepts to Advanced Applications: Using Bloom's Taxonomy to Inform Graduate Course Design, Academy of Educational Leadership Journal, 12(3), 99-106.

Blair, B., and Millea, M. (2004). Student academic performance and compensation: the impact of cooperative education, College Student Journal, 38 (4), 643-653.

Bloom, B.S. (1956). Taxonomy of educational objectives, Handbook 1: Cognitive domain, New York: Longman.

Boud, D. (2000). Sustainable assessment: Rethinking assessment for the learning society, Studies in Continuing Education, 22 (2), 151-167.

Buhalis, D., and Law, R. (2008). Progress in information technology and tourism management: 20 years on and 10 years after the Internet-the state of eTourism research, Tourism Management, 29 (4), 609-623.

Cantoni, L., Kalbaska, N., and Inversini, A. (2009). E-learning in tourism and hospitality: A map, Journal of Hospitality, Leisure, Sport and Tourism Education, 8 (2), 148-156.

Chin, W.W. (1998). Issues and opinions on structural equation modelling, MIS Quarterly, 22(1), 7-16

Chin, W.W. (2010). How to Write Up and Report PLS Analyses, In Vinzi, V.E., Chin, W.W., Henseler, J., and Wang, H. (Eds.), Handbook of Partial Least Squares: Concepts, Methods and Applications in Marketing and Related Fields (655-690), Berlin: Springer.

Cobanoglu, C., and Berezina, K. (2011). The impact of the use of blogs on students' assignment engagement, Journal of Hospitality, Leisure Sport and Tourism Education, 10 (1), 99-105.

Coffield, F., Moseley, D., Hall, E., and Ecclestone, K. (2004). Learning styles and pedagogy in post-16 learning: A systematic and critical review, London, UK: Learning and Skills 
Research Centre, Retrieved: http://sxills.nl/lerenlerennu/bronnen/Learning.pdf, accessed; 20/1/2017.

Conrad, D. (2006). E-Learning and social change: An apparent contradiction. In. Beaudoin, M. (eds.), Perspectives on higher education in the digital age (21-33), New York, Nova Science Publishers.

De Vos, A., De Hauw, S., and Van der H.B. (2011). Competency development and career success: The mediating role of employability, Journal of Vocational Behavior, 79, 438447.

Eftimie, R., (2013). The Role of Pupil- Teacher Communication within E-Learning Communities, Is E-Learning a Good Tool in Improving Educational Performance?, The $2^{\text {nd }}$ International Conference on Integrated Information, Procedia - Social and Behavioral Sciences, 73, 196-204.

El-Khouly, M.M., (2010). eLearning in Egypt, (in) Demiray, U. et al. (eds.), E-Learning Practices, Volume I, Cases on challenges facing e-learning and national development: Institutional Studies and Practices, Anadolu University, 107-131.

Eraqi, M., Abou-Alam, W., Belal, M., and Fahmi, T. (2011). Attitudes of undergraduate students toward e-learning in tourism: The case of Egypt, Journal of Teaching in Travel and Tourism, 11, 325-348.

Eurico, S.T., da-Silva, J.A.M., and do-Valle, P.O, (2015). A model of graduates' satisfaction and loyalty in tourism higher education: The role of employability, Journal of Hospitality, Leisure, Sport and Tourism Education, 16, 30-42.

Fakomogbon, M.A., Omiola, M.A., Awoyemi, S.O., and Mohammed, R.E., (2014). Effect of computer assisted instructional package on the performance of students in Mathematics in Ilorin metropolis, European Scientific Journal, 10 (25), 196-206.

Fermoso, A. M., Mateos, M., Beato, M.E., and Berjon, R., (2015). Open linked data and mobile devices as e-tourism tools, A practical approach to collaborative e-learning, Computers in Human Behavior, 51, (B), 618-626.

Fornell, C., and Larcker, D., (1981). Evaluating structural equation models with unobservable variables and measurement error, Journal of Marketing Research, 18, 39-50.

Garrison, D.R., and Kanuka, H., (2004). Blended learning: Uncovering its transformative potential in higher education, Internet and Higher Education, 7, 95-105.

Ghanekar, A. (2011). Identification and Comparison of Learning styles and Personality types: of undergraduate hospitality and tourism management students from Thailand and Lao PDR, LAP LAMBERT Academic Publishing.

Hair, J.,F., Black, W.C., Babin, B.J., Anderson, R.E., and Tatham, R. (2006). Multivariate data analysis. $6^{\text {th }}$ Edition, Pearson Prentice Hall, Upper Saddle River, New Jersey.

Hair, J.F., Black, W.C., Babin, B.J., and Anderson, R.E. (2010). Multivariate Data Analysis, $7^{\text {th }}$ Edition, Pearson Prentice Hall, Upper Saddle River, New Jersey.

Hair, J.F., Ringle, C.M., and Sarstedt, M. (2011). PLS-SEM: Indeed a Silver Bullet, Journal of Marketing Theory and Practice, 19 (2), pp139-151.

Halawi, L.A., Pires, S., McCarthy, R.V. (2009). An Evaluation of E-Learning on the Basis of Bloom's Taxonomy: An Exploratory Study, Journal of Education for Business, Washington, 84(6), 374-380.

Hiltz, S.R., and Turoff, M. (2005). Education goes digital: The evolution of online learning and the revolution in higher education, Communications of the ACM, 48 (10), 59-64. 
Hošková-Mayerová, Š., and Rosická, Z., (2015). E-Learning Pros And Cons: Active Learning Culture?, Procedia - Social and Behavioral Sciences, 191, 958-962.

Hsu, I-C., and Wu, P-Y., (2014). How Do Hospitality and Tourism Undergraduate Students Learn? From a Perspective of Learning Styles, Journal of Tourism and Hospitality Management, 2, (9), 357-363.

Huang, Y.C., Backman, S.J., Chang, L.L., Backman, K.F., and McGuire, F.A. (2013). Experiencing student learning and tourism training in a 3D virtual world: An exploratory study, Journal of Hospitality, Leisure, Sport and Tourism Education, 13, 190-201.

Karaskova, T., (2014). Application of revised bloom's taxonomy in the branch of tourism, 17th International Colloquium on Regional sciences, Faculty of economics and administration, Masaryk University, Hustopeče, June 18-20, 2014, Czech Republic, DOI: 10.5817/CZ.MUNI.P210-6840-2014-116.

King, C., and So, K. (2014). Creating a virtual learning community to engage international students, Journal of Hospitality and Tourism Education, 26 (3), 136-146.

King, F., Young, M.F., Drivere-Richmond, K., and Schrader, P.G. (2001). Defining distance learning and distance education, Association for the Advancement of Computing in Education journal, 9 (1), 1-14.

Kluge, S., and Riley, L. (2008). Teaching in virtual worlds: Opportunities and challenges, Issues in Informing Science and Information Technology, 5, 127-135.

Knowles, T., Teixeira, R.M., Egan, D., (2003). Tourism and hospitality education in Brazil and the UK: a comparison, International Journal of Contemporary Hospitality Management, $15,45-51$.

Kolb, A. Y., and Kolb, D. A. (2006): Learning styles and learning spaces: enhancing experiential learning in higher education, Academy of Management Learning and Education, 4 (2), 193-212.

Kolb, D.A. (1984). Experiential learning: Experiences as the source of learning and development. Vol.1, Englewood Cliffs, NJ: Prentice-Hall.

Kolb, Y.A., and Kolb, D.A. (2005). The Kolb learning style inventory-Version 3.1, Technical specifications, Boston, MA, the HayGroup.

Kontopoulos, E., Vrakas, D., Kokkoras, F., Bassiliades, N., and Vlahavas, I. (2008). An ontology-based planning system for e-course generation, Expert Systems with Applications, 35 (1-2), 398-406.

Krejcie, R.V., and Morgan, D.W., (1970). Determining sample size research activities, Educational and Psychological Measurement, 30, 607-610.

Liburd, J., and Hjalager, A-M (2010). hanging Approaches Towards Open Education, Innovation and Research in Tourism, Journal of Hospitality and Tourism Management, 17, 12-20.

Liburd, J.J., and Christensen, I-M.F., (2013). Using web 2.0 in higher tourism education, Journal of Hospitality, Leisure, Sport and Tourism Education, 12, 199-108.

Lin, T-B., Li, J-Y., Deng, F., and Lee, L. (2013). Understanding New Media Literacy: An Explorative Theoretical Framework, Educational Technology and Society, 16 (4), 160-170.

Lohman, L., Austin, E., Borgen, B., and Salo W.S. (2015). Business perspectives on faculty internships: not just for students anymore?. Journal for Advancement of Marketing Education, 23 (2), 23-33.

Lwoga, E., (2012). Making learning and Web 2.0 technologies work for higher learning institutions in Africa, Campus-Wide Information Systems, 29 (2), 90-107. 
Maher, A. (2004). Learning Outcomes in Higher Education: Implications for Curriculum Design and Student Learning, Journal of Hospitality, Leisure, Sport and Tourism Education, 3 (2), 46-54.

McGee, P. and Reis, A. (2012). Blended course design: A synthesis of best practices, Journal of Asynchronous Learning Networks, 16 (4), 7-22.

Moore, J, Dickson-Deane, C., and Galyen, K. (2011). E-Learning, online learning and distance learning environments: Are they the same? Internet and Higher Education, 14, 129-135.

Murphy, J., Kalbaska, N., Horton-Tognazzini, L., and Cantoni, L. (2015). Online Learning and MOOCs: A Framework Proposal. In: Tussyadiah I., Inversini A. (eds) Information and Communication Technologies in Tourism 2015. Springer, Cham

Murphy, J., Kalbaska, N., Williams, A., Ryan, P., Cantoni, L., and Horton-Tognazzini, L. (2014). Massive open online courses: Strategies and research areas, Journal of Hospitality and Tourism Education, 26 (1), 39-43.

Nicol, D. J., and Macfarlane-Dick, D. (2006). Formative assessment and self-regulated learning: a models and seven principles of good feedback practice, Studies in Higher Education, 31 (2), 199-218.

Nunnally, J.C., (1978), Psychometric Theory, McGraw Hill, New York.

Oblinger, D.G., and Oblinger, J.L. (2005). Educating the Net generation, EDUCAUSE, at, http://net.educause.edu/ir/library/pdf/pub7101.pdf, accessed 20/1/2017.

OECD (2016). OECD Tourism Trends and Policies 2016, OECD Publishing, Paris, http://dx.doi.org/10.1787/tour-2016-en.

Papamarcos, S.D. (2002). The 'next wave' in service-learning: Integrative team-based engagements with structural objectives. Review of Business, 23(2), 31-38.

Pavel, A.P., Fruth, A., and Neacsu, M.N. (2015). ICT and E-Learning-Catalysts for innovation and quality in higher education, Procedia Economics and Finance, 23, 704-711.

Pittman, J., Rutz, E., and Elkins, V. (2006). Technology enabled content in engineering technology and applied science curriculum: Implications for online content development in teacher education, Journal of Interactive Online Learning, 5 (1), 32-56.

Pollock, A., and Ritchie, J.R.B., (1990). Integrated strategy for tourism education/ training, Annals of Tourism Research, 17 (4), 568-585.

Postigo, H. (2011). Questioning the web 2.0 discourse: Social roles, production, values, and the case of the human rights portal, The Information Society: An International Journal, 27 (3), 181-193.

Ringle, C.M., Wende, S., and Becker, J.-M. (2015). "SmartPLS 3." Boenningstedt: SmartPLS $\mathrm{GmbH}$, http://www.smartpls.com

Robinson, R., Ruhanen, L., and Breakey, N. (2016): Tourism and hospitality internships: influences on student career aspirations, Current Issues in Tourism, 19 (6), 513-527.

Romiszowski, A.J. (2004). How's the E-learning Baby? Factors Leading to Success or Failure of an Educational Technology Innovation, Educational Technology, 44 (1), 5-27.

Ruhanen, L. (2005). Bridging the Divide between Theory and Practice Experiential Learning Approaches for Tourism and Hospitality Management Education, Journal of Teaching in Travel \& Tourism, 5 (4), 33-51.

Ruhanen, L., Robinson, R., and Breakey, N. (2013). A tourism immersion internship: student expectations, experiences and satisfaction, Journal of Hospitality, Leisure, Sport and Tourism Education, 13, 60-69. 
Semley, N., Huang, R., and Dalton, J., (2016). Feedback for Learning Development: Tourism students' perspective, Journal of Hospitality, Leisure, Sport \&Tourism Education, 19, 4153.

Sigala, M., (2002). The evolution of Internet pedagogy: Benefits for tourism and hospitality education, Journal of Hospitality, Leisure, Sport, and Tourism Education, 1 (2), 27-42.

Sigala, M., (2012). Investigating the role and impact of geo-visualization and geo-collaborative portals on collaborative e-learning in tourism education, Journal of Hospitality, Leisure, Sport and Tourism Education, 11, 50-66.

Singh, N, and Lee, M.J. (2008). Exploring perceptions toward education in 3D virtual environments: An introduction to "Second Life", Journal of Teaching in Travel and Tourism, 8, (4), 315-327.

Solvie, P., and Kloek, M. (2007). Using technology tools to engage students with multiple learning styles in a constructivist learning environment, Contemporary Issues in Technology and Teacher Education, 7, (2), 7-27.

Songkram, N., Khlaisang, J., Puthaseranee, B., and Likhitdamrongkiat, M. (2015). E-learning system to enhance cognitive skills for learners in higher education, Procedia - Social and Behavioral Sciences, 174, 667-673.

Stansbie, P., and Nash, R. (2016). Customizing internship experiences by emphasis area: the key to increased satisfaction and motivation in hospitality and tourism management students, Journal of Hospitality and Tourism Education, 28 (2), 71-84.

Stansbie, P., Nash, R., and Chang, S., (2016). Linking internships and classroom learning: A case study examination of hospitality and tourism management students, Journal of Hospitality, Leisure, Sport and Tourism Education, 19, 19-29.

Stansbie, P., Nash, R., and Jack, K. (2013). Internship design and its impact on student satisfaction and intrinsic motivation, Journal of Hospitality and Tourism, Education, 25 (4), 157-168.

Tabachnick, B.G., and Fidell, L.S. (2007). Using Multivariate Statistics, Fifth Edition. Boston: Pearson Education, Inc.

Tarhini, A., Hone, K., and Liu, X. (2013). User acceptance towards Web-based learning systems: Investigating the role of social, organizational and individual factors in European higher education, Procedia Computer Science, 17, 189-197.

Twining, P. (2009). Exploring the educational potential of virtual worlds some reflections from the SPP, British Journal of Educational Technology, 43 (3), 496-514.

UNESCO (2002). Teacher education guidelines: Using open and distance learning, Paris, France: Higher Education Division, Teacher Education Section.

Vinzi, V.E., Chin, W.W., Henseler, J., and Wang, H. (2010). Handbook of Partial Least Squares: Concepts, Methods and Applications in Marketing and Related Fields, Berlin: Springer.

Wan, C. S., Yang, J. T., Cheng, S. Y., and Su, C. (2013). A longitudinal study on internship effectiveness in vocational higher education, Educational Review, 65 (1), 36-55.

Yang, H. J., and Cheung, C. (2014). Towards an understanding of experiential learning in China's hospitality education, Journal of China Tourism Research, 10 (2), 222-235.

Zagonari, F., (2009). Balancing tourism education and training, International Journal of Hospitality Management, 28 (1), 2-9.

Zull, J.E. (2002). The art of changing the brain: Enriching teaching by exploring the biology of learning, Sterling, VA: Stylus. 